\title{
Sustainable model for the implementation of a green building project
}

\author{
Veronika Luchkina ${ }^{1, *}$ \\ ${ }^{1}$ Moscow State University of Civil Engineering, 129337, 26, Yaroslavskoye Shosse, Moscow, Russia
}

\begin{abstract}
The problem of today is a complex study of the multicomponent geotechnical system of large green building projects. The essence of the green building project is to introduce a set of technologies to improve the construction process and minimize future costs. A comprehensive implementation of energy-efficient technologies considered by the author allows obtaining an overall reduction in heat consumption from $30 \%$ to $70 \%$, depending on the list of measures and selected technical solutions, as well as on the initial technical condition of the house. Based on these calculations, during the period under consideration, the NPV indicator is positive, and as a result, the proposed project pays off. The payback period of the Energy Efficient Home project is within 10,29 years, and the project is quite efficient. Taking into account the research data, it is planned to develop an algorithm for assessing the geomonitoring of environmental impacts in the development of green building projects.
\end{abstract}

\section{Introduction}

The efficiency of regional and municipal ecological regulation for sustainable development goals can be reached only at the general greening of control systems. A problem of today is a complex study of the multicomponent geotechnical system of large green building projects. The geotechnical system shouldn't be aggressive for the environment. Therefore, development of environmentally friendly construction projects is very relevant.

At the beginning of 2017, SDK-GROUP LLC initiated a project for construction of an "Energy Efficient House" residential complex. A land in the central part of the city with a developed infrastructure and convenient location of transport routes was selected for construction of this complex.

The essence of the "Energy Efficient House" project is to introduce a set of technologies to improve the construction process and minimize costs in the future. The planned implementation dates are - January 2017 - December 2019. A project to improve the energy efficiency of apartment buildings provides introduction of energy saving measures that ensure a significant reduction in energy consumption. The implementation of energyefficient projects allows minimizing payments for utilities (during the payback period of capital investments in the project) and to significantly reduce them (after the completion of

* Corresponding author: luchkinavv@mail.ru angela-1309.m@yandex.ru 
the payback period). Along with this, some important arguments in favor of such projects for co-owners, are:

- a significant improvement in comfort of living conditions in apartments;

- an increase in the market value of housing in thermo-modernized houses;

- an increase in the effective life of such houses by about 30 years.

The forecast of the International Energy Agency (IEA) shows the tendency of changing of the world energy balance structure in the direction of energy efficiency growth, increase of the usage of renewable energy sources (RES), wider application of modern technologies for $\mathrm{CO} 2$ capture, and change-over to new fuels in transport. These changes allow diversifying the fuel and energy complexes of countries and reducing greenhouse gas emissions significantly [1].

The main reason for the high energy consumption of houses is due to excessive heat loss through the building envelope, as well as the low efficiency of their heating systems [2].

In the process of project implementation, an additional warming of the house is carried out with the mandatory modernization of the heating system, since only this kind of an integrated approach allows to achieve an optimal result. Along with this, co-owners can also be offered measures to modernize the hot water supply and lighting systems, which will contribute to the project's effectiveness. At the same time, an optimal list of energy saving measures can be identified and offered to co-owners only on the basis of a detailed survey of the technical condition and energy audit of the house, as well as the implementation of appropriate calculations.

The development and implementation of a project to improve the energy efficiency of an apartment building can be conditionally presented as a sequential scheme that includes stages. High-quality implementation of each of these stages ensures minimization of risks for the project as a whole and creates conditions for achieving its goals (namely, energy saving) [3].

At the same time, from the very beginning, co-owners need to understand that measures to improve the energy efficiency of an apartment building, as a rule, in their essence are related to works on technical re-equipment, and less often to renovation or major repairs, because their results improve operational and technical-economic building indicators. This will require an additional involvement in the development and implementation of the project by qualified specialists to perform the necessary list of services and works.

Of course, the introduction of energy-efficient measures in homes requires additional financial investments, which in total terms, usually, exceed payments in their current maintenance.

An assessment of potential for energy saving and saving money for the energy use in an apartment building is a key factor that affects the decision of co-owners on the implementation of energy-efficient measures.

\section{Materials and Methods}

At the initial stage of preparing a decision on the implementation of energy-efficient measures, it is recommended that co-owners of an apartment building use a simplified methodology to pre-determine the potential for energy saving. The simplified methodology can be applied without a detailed energy survey of an apartment building and does not require special knowledge, but it provides an estimate of an approximate (with a possible deviation of 10-20\%) reduction in energy consumption. Despite this, the obtained indicators are sufficient for the co-owners to understand the potential for energy saving and for making a fundamental decision on the implementation of energy-efficient measures, 
determining the list of such measures and their priority, as well as the expected economic effect [4].

At the same time, from the very beginning, co-owners need to understand that measures to improve the energy efficiency of an apartment building, as a rule, in their essence are related to works on technical re-equipment, and less often to renovation or major repairs, because their results improve operational and technical-economic building indicators. This will require an additional involvement in the development and implementation of the project by qualified specialists to perform the necessary list of services and works.

Considering that the cost of thermal energy is the most significant in the cost-structure of the energy consumed in an apartment building, in order to understand the main indicators and justify the feasibility of the project, it is recommended first to compare the indicators of current thermal energy consumption (Q) in the base period and the calculated thermal energy consumption indicators (After), which can be achieved as a result of the implementation of thermomodernization [5].

If there is a common heat meter in the house, the base volume of the current heat consumption in thermal modernization (Q), which is used for further calculations of the potential for energy saving, is determined as an arithmetic average of the actual indicators of the meter over the last three years.

In case of a principle decision to implement the project and to attract specialists to it, the calculated data on the volume of current consumption of thermal energy in the base period should be compared with the calculated data obtained from the survey of the technical condition of the house, the energy research data.

For a simplified assessment of an economic effect of the implementation of measures to improve energy efficiency, you can use the averaged data on the potential for energy saving, shown in Table 1 [6].

Table 1. Data on the energy saving potential of an apartment building

\begin{tabular}{|c|c|c|c|}
\hline $\begin{array}{c}\text { Structural } \\
\text { element }\end{array}$ & Technical solution & $\begin{array}{c}\text { Energy saving } \\
\text { potential }\end{array}$ & $\begin{array}{c}\text { Average payback } \\
\text { period (years) }\end{array}$ \\
\hline Walls & Warming & $18-25 \%$ & $7-10$ \\
\hline $\begin{array}{c}\text { Windows, exterior } \\
\text { doors }\end{array}$ & replacement & $15-20 \%$ & 15 \\
\hline Attic and attic floor & Warming & $5-10 \%$ & $10-12$ \\
\hline Basement floor & Warming & $5-10 \%$ & $7-10$ \\
\hline $\begin{array}{c}\text { Ventilation } \\
\text { systems }\end{array}$ & $\begin{array}{c}\text { The device of the supply and } \\
\text { exhaust valves; } \\
\text { Capture recuperators; } \\
\text { Transition to forced exhaust } \\
\text { ventilation }\end{array}$ & $5-35 \%$ & $5-8$ \\
\hline $\begin{array}{c}\text { General Electric } \\
\text { Power Systems }\end{array}$ & $\begin{array}{c}\text { Installation of lighting control } \\
\text { devices }\end{array}$ & $5 \%$ & $2-3$ \\
\hline
\end{tabular}

Indicators in the table show how the introduction of each of the listed measures can roughly reduce the amount of consumption of thermal and electric energy in comparison with the base level of its consumption.

Using data from the specified table to calculate potential energy savings, it is necessary to bear in mind that priority must be given to comprehensive solutions that provide the most long-lasting effect, instead of individual measures. At the same time, it will be a mistake to carry out a simple arithmetic addition of these indicators, when calculating the predicted result of implementing a set of measures to improve the thermal performance of a building. 


\section{Results}

A comprehensive implementation of such measures allows achieving an overall reduction in heat consumption from $30 \%$ to $70 \%$, depending on the list of measures and selected technical solutions, as well as on the initial technical condition of the house [6].

For creation of the "Energy Efficient House" residential complex project, the resources necessary for the implementation of individual tasks have already been identified. In this project, the discount rate $\mathrm{r}$ is taken as $12.81 \%$ when taking into account part of the funds raised and part of the loan in the amount of investment.

Consequently, based on the analysis of these results, we can conclude that for the project in question, the value of NPV invested capital and NPV equity in the first year of the project is negative and amounts to 2,030 million RUB in 2017. and - 358 million RUB respectively [7-8].

So in 2018, NPV invested capital and NPV equity have increased and amounted to 1,201 million RUB and 261 million RUB. Based on these calculations, during the period under consideration, the NPV indicator is positive, and as a result, the proposed project pays off [9-10].

\section{Discussion}

Warming the house is achieved by increasing the resistance to heat transfer walling.

Thus, the heat transfer resistance of external walls $(\mathrm{RBc})$ is $0.65 \mathrm{~m} 2 \mathrm{~K} / \mathrm{W}$

$\mathrm{R}$ sun $=/ \gamma \mathrm{p}(1)$

where $\partial=0.38 \mathrm{~m}$ is wall thickness,

$\gamma \mathrm{p}=0.58 \mathrm{~W} /(\mathrm{m} \cdot \mathrm{K})$ - thermal conductivity of the brickwork

The heat transfer resistance of the attic (Rpg) and basement floors (Rpp) is also calculated using a similar formula, but it takes into account the multi-layer characteristic of these floors, each of the layers of which has different thickness and thermal conductivity.

In particular, to overlap the attic $(\mathrm{Rpg})-0.8 \mathrm{~m} 2 \mathrm{~K} / \mathrm{W}$, is calculated on the basis that the thickness of the reinforced concrete floor slab is $0.22 \mathrm{~m}$, the thermal conductivity of concrete is $\lambda \mathrm{p}=2.04 \mathrm{~W} /(\mathrm{m} \bullet \mathrm{K})$, and $130 \mathrm{~mm}$ slag backfill $\lambda \mathrm{p}=0.19 \mathrm{~W} /(\mathrm{m} \bullet \mathrm{K})$.

Heat transfer resistance

$\mathrm{Rpg}=0.22 / 2.04+0.130 /, 19=0.8 \mathrm{~m} 2 \mathrm{~K} / \mathrm{W}$

For the ceiling over the basement (Rpp) $-1.46 \mathrm{~m} 2 \mathrm{~K} / \mathrm{W}$.

Calculated on the assumption that the concrete slab thickness is $0.22 \mathrm{~m}$, the thermal conductivity of the concrete $\lambda \mathrm{p}=2,04 \mathrm{~W} /(\mathrm{m} \cdot \mathrm{K}), 50 \mathrm{~mm}$ polystyrene plate $\lambda \mathrm{p}=0,045 \mathrm{~W}$ $/(\mathrm{m} \cdot \mathrm{K})$, plate $50 \mathrm{~mm}$ with cement-sand mortar $\lambda \mathrm{p}=0.81 \mathrm{~W} /(\mathrm{m} \bullet \mathrm{K})$ by sand filling 110 $\mathrm{mm} \lambda \mathrm{p}=0.58 \mathrm{~W} /(\mathrm{m} \cdot \mathrm{K})$.

Heat transfer resistance Rpp $=0.22 / 2.04+0.05 / 0.045+0.05 / 0.81+0.11 / 0.58=$ $1.46 \mathrm{~m} 2 \mathrm{~K} / \mathrm{W}$ Regulatory values of resistance to heat transfer of enclosing structures for residential buildings, which must be achieved after thermal modernization (Rafter).

At the same time, if a decision is made on the advisability of upgrading the power supply systems, the result from the introduction of appropriate measures will (of course, not significantly) affect the thermal performance of the house. Therefore, the volume of possible reduction in electricity consumption for general purposes and cash savings, when paying for them, is calculated separately, and the projected indicators in this way can also be subjected to comparison with the corresponding indicators in the base period of consumption.

\section{Conclusion}


One of the main indicators of project profitability is the internal rate of return or IRR. The economic essence of this indicator is that it acts as an expected rate of return (return on investment) or the maximum allowable level of investment costs in the proposed project. For the "Energy Efficient House" project, IRR is 13.93\%.

Since cash receipts over the years are not equal, the payback period of the project is calculated on an accrual basis. Consequently, the payback period of the Energy Efficient House project is within 10,29 years.

Thus, it can be summarized that the project to open the "Energy Efficient House" Residential Complex is quite efficient. Risk assessment is carried out during project planning, including both qualitative and quantitative analysis, that is, a risk assessment method in which various matrices appear. The advantage of this method is that in such cases it is possible to combine qualitative or mixed (qualitative and quantitative) estimates of consequences and probabilities. Also, the matrix can be successfully used to determine (rank) the level of risk. In this case, the rows and columns of the matrix are determined by its area of application. However, it should be remembered that the developed matrix should fully correspond to the specific situation being considered (analyzed). The matrix approach is simplified and is applicable in cases where there is not enough data to be analyzed by other methods. Also, this method is used when a sufficiently detailed analysis of the situation requires large expenditures for carrying out a quantitative analysis, but these costs themselves are not justified. For the organization of evaluation using a matrix, the contractor usually develops scales of consequences and probabilities for a particular type of task, as well as a general view of the matrix itself. Despite the simplicity of this method, there are also disadvantages to it. First, as a rule, the matrix is developed for the analysis of a specific situation. Secondly, it may be a challenge for the contractor to develop rating scales. Thirdly, the level of training of a specialist who is entrusted with the implementation of such a procedure can significantly affect the results of the assessment.

The process of assessing the risks identified in the course of implementation of the sustainable development project is based on an assessment of the degree of response of the planned activities on the risk events for each of the possible impacts based on the current value of the risk index ( $\mathrm{R}$ values for each of the risks in the current analysis of the project).

Taking into account the research data, it is planned to develop an algorithm for assessing the geomonitoring of environmental impacts in the development of green building projects.

\section{References}

1. V. V. Luchkina, IOP Conf. Series: Earth and Environmental Science, 90, 1-6 (2017)

2. R. R. Kazaryan, MATEC Web of Conferences, 193, 01009 (2018)

3. R. R. Kazaryan, MATEC Web of Conferences, 193, 04023 (2018)

4. R. R. Kazaryan, MATEC Web of Conferences, 193, 01008 (2018)

5. R. R. Kazarya, E3S Web of Conferences, 33, 02071 (2018)

6. R. R. Kazaryan, MATEC Web of Conferences, 170, 05001 (2018)

7. S. A. Sinenko, MATEC Web of Conferences, 21, 09007 (2017)

8. A. Mottaeva, MATEC Web of Conferences, 193, 01022 (2018)

9. E. Vasilyeva, MATEC Web of Conferences, 170, 01050 (2018)

10. B. V. Zhadanovsky, S. A. Sinenko, Computing in Civil and Building Engineering Proceedings International Conference, 1, 137-142 (2014) 